\title{
FORMULASI SIRUP HERBAL DAUN KELOR (Morringa oleifera) DENGAN EKSTRAK BUNGA ROSELLA (Hibiscus sabdariffa L.)
}

\author{
The Formulation of Herbal Syrup from Moringa Leaf (Morringa oleifera) \\ with Rosella Flower Extract (Hibiscus sabdariffa L.)
}

\author{
Alfonsus Airnando Bahtiam Ananta'), Merkuria Karyantia'), \\ Yannie Asrie Widanti ${ }^{1}$ \\ 1)Fakultas Teknologi dan Industri pangan Universitas Slamet Riyadi Surakarta, \\ Jl. Sumpah Pemuda 18 Joglo Kadipiro Surakarta 57136 \\ Email: nandoanantha@gmail.com
}

\begin{abstract}
ABSTRAK
Sirup termasuk minuman instan yang memiliki rasa dan aroma tertentu. Beberapa tanaman dapat dimanfaatkan sebagai bahan baku untuk formulasi sirup herbal antara lain daun kelor dan bunga rosella. Sirup daun kelor dan bunga rosella merupakan salah satu potensi sirup herbal dengan kandungan aktivitas antioksidan yang mudah dikonsumsi dan baik bagi kesehatan. Penelitian ini bertujuan untuk menentukan formulasi sirup herbal daun kelor dengan ekstrak bunga rosella sebagai minuman kesehatan bagi konsumen dengan aktivitas antioksidan yang tinggi. Penelitian dilakukan dengan Rancangan Acak Lengkap (RAL) faktorial yang terdiri dari 2 faktor. Faktor pertama yaitu daun kelor $(5,10,15 \mathrm{~g})$ sedangkan faktor kedua ekstrak bunga rosella $(5,10,15 \mathrm{~g})$. Hasil penelitian menunjukkan bahwa kombinasi perlakuan konsentrasi daun kelor : bunga rosella 15:15 merupakan perlakuan terbaik didasarkan pada aktivitas antioksidan dan uji organoleptik terbaik yang terdapat pada sirup. Karakteristik sirup adalah $\mathrm{pH}$ 3,82, vitamin C 20,40 mg/100 $\mathrm{ml}$, total padatan terlarut $41,33 \%$, aktivitas antioksidan DPPH $48,97 \%$, gula total $13,82 \%$, serta uji organoleptik terhadap warna 1,80 (merah muda), flavor kelor 2,56 (terasa kelor), flavor rosella 1,89 (terasa rosella), rasa asam 1,87 (terasa asam) dan kesukaan keseluruhan 1,72 (cukup disukai).
\end{abstract}

Kata kunci: Formulasi sirup, daun kelor, rosella

\begin{abstract}
Syrup was the instant drink which have spesific taste and aroma. Some herbs can be used as ingredients for herbal syrup formulation, for example moringa leaves and rosella flower extract. Potency of this herbal syrup are high antioxidant and easy to drink and good for health. This research aimed to determine of moringa leaf and rosella flower extracts for herbal syrup formulation as healthy drink for consumer with high activity of anti-oxidants. The research performed with completely randomized design (CRD) factorial that consists of 2 factors. The first was moringa leaf $(5,10,15 \mathrm{~g})$ and the second was rosella flower extracts $(5,10,15 \mathrm{~g})$. The result showed that the best combination of moringa leaf: rosella flower extract was 15:15, which have highest

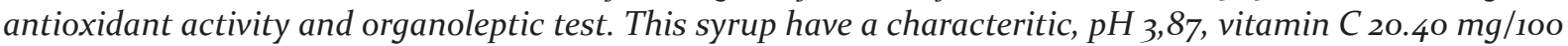
cc, total dissolved solid (TDS) 41.33\%, anti-oxidants activity $48.7 \%$, total sugar $13.82 \%$, and also organoleptic test to the color 1.0, moringa flavor 2.6, rosella flavor 1.9, sour taste 1.7, and total fondness by 1.2.
\end{abstract}

Keywords: Syrup formulation, moringa leaf, rosella 


\section{PENDAHULUAN}

Indonesia adalah negara yang kaya akan sumber daya alam. Mulai dari beraneka ragam jenis tanaman yang dapat dimanfaatkan sebagai sumber bahan pangan, ilmu pengetahuan, daya tahan tubuh dan sumber kehidupan. Beberapa tanaman yang dapat dimanfaatkan sebagai bahan baku tersebut antara lain daun kelor (Moringa oleifera) dan bunga rosella (Hibiscus sabdariffa L.)

Daun kelor berkhasiat sebagai suplemen yang kaya zat gizi untuk ibu menyusui dan anak pada masa pertumbuhan. Pemanfaatan daun kelor dilakukan dengan cara mengkonsumsi daunnya, diekstrak dan dibuat tepung. Daun kelor juga dapat disajikan atau diolah sebagai jamu tradisional, sirup dan lain-lain (Broin, 2010).

Bunga rosella berkhasiat sebagai diuretik dan koleretik, yaitu membantu melancarkan peredaran darah, menurunkan kekentalan darah, mencegah tekanan darah tinggi, meningkatkan kinerja usus, antiinfeksi bakteri, memperlambat pertumbuhan batu ginjal, serta meningkatkan daya tahan tubuh (Maryani dan Kristina, 2008).

Kesadaran masyarakat terhadap makanan dan minuman yang menyehatkan serta alami merupakan salah satu pendukung, sehingga daun kelor dan bunga rosella dikenal masyarakat. Daun kelor maupun bunga rosella dikenal sebagai tanaman obat yang biasa dikonsumsi oleh masyarakat sebagai obat herbal. Masyarakat awam kurang mengetahui khasiat dari daun kelor dan bunga rosella dan kurang kreatif dalam pengolahan. Oleh karena itu diperlukan penyajian inovatif dari kedua bahan tersebut agar masyarakat lebih mengenal dan tertarik mengkonsumsi kelor dan rosella.

\section{METODE PENELITIAN}

\section{Alat}

Alat yang digunakan dalam penelitian antara lain tabung reaksi merk Pyrex, vortex, pipet volum $1 \mathrm{ml}$, erlemeyer merk Pyrex, beker glass merk Pyrex, pipet volum $10 \mathrm{ml}$, ball pipet merk D\&N, tabung erlemeyer merk, $\mathrm{pH}$ meter merk Oakion, refraktometer merk Atago dan
Sprektrofotometer merk Thermo Scientific tipe GENESYS $10 S$ UV-VIS.

\section{Bahan}

Bahan yang digunakan dalam penelitian antara lain daun kelor kering, bunga rosella kering yang diperoleh di Pasar Gede Solo, sedangkan bahan untuk analisis kimia antara lain amilum $1 \%$, Iodin o,o1 N, $\mathrm{HCl}$ $30 \%$, NAOH 45\%, dan DPPH o,1 mM.

\section{Rancangan Percobaan}

Dalam penelitian ini rancangan percobaan yang digunakan adalah Rancangan Acak Lengkap faktorial dengan dua faktor yaitu konsentrasi daun kelor kering $(5,10,15 \mathrm{~g})$ dan konsentrasi bunga rosella kering $(5,10,15 \mathrm{~g})$ yang digunakan pada pembuatan sirup herbal.

Rancangan tersebut memperoleh 9 kombinasi perlakuan. Masing - masing perlakuan diulang sebanyak dua kali. Data yang diperoleh dianalisis dengan uji sidik ragam pada jenjang nyata o,05. Jika ada beda nyata dilanjutkan Uji Tukey untuk mengetahui beda nyata antar perlakuan pada tingkat signifikan $5 \%$.

\section{TAHAP PENELITIAN \\ Pembuatan Ekstrak Daun Kelor Dengan Bunga Rosella}

Pemilihan daun kelor kering (dipisahkan antara daun dengan batang) dan bunga rosella merah kering, kemudian menghaluskan dengan blender waktu 10-20 detik. Lalu kedua bahan ditimbang sesuai perlakuan. Untuk memperolah ekstrak melalui proses penyeduhan menggunakan air $250 \mathrm{ml}$ dalam suhu $100^{\circ} \mathrm{C}$ selama 5-10 menit kemudian disaring untuk memisahkan antara endapan dan ekstrak sehingga mendapatkan ekstrak daun kelor dan bunga rosella (Hastuti, 2012).

\section{Pembuatan Sirup Herbal Kelor-Rosella}

Ekstrak daun kelor dan bunga rosella 250 ml yang sudah diekstrak, ditambahkan gula 100 gram, dilakukan proses pemanasan pada suhu $100^{\circ} \mathrm{C}$ selama 15 menit, supaya bahan menjadi homogen (Mukaromah et al, 2010). 


\section{Cara Pengumpulan Data}

Analisis yang digunakan dalam penelitian ini yaitu analisis kimia, fisika dan uji organoleptik. Analisis kimia dan fisika terdiri dari analisis vitamin $\mathrm{C}$ dengan metode titrasi iodium (Sudarmadji et al, 1984), analisis $\mathrm{pH}$ menggunakan $\mathrm{pH}$ meter (Maitimu et al, 2012), analisis gula total dengan metode Nelson
(Sudarmadji et al, 1997), analisis padatan terlarut menggunakan alat refraktometer Abbe (Pomeranz dan Meloan, 1980), analisis antioksidan dengan metode DPPH (Yen and Chen, 1995) dan uji organoleptik dengan metode scoring test (Kartika et al, 1988) meliputi: warna, flavor kelor, flavor rosella, rasa asam, dan kesukaan keseluruhan.

HASIL DAN PEMBAHASAN

\section{Analisis Kimia}

Tabel 1. Rangkuman Hasil Analisis Kimia dan Fisika Sirup Herbal Kelor-Rosella

\begin{tabular}{|c|c|c|c|c|c|c|}
\hline \multirow[b]{2}{*}{$\begin{array}{l}\text { Konsentrasi } \\
\text { Daun Kelor }\end{array}$} & \multirow[b]{2}{*}{$\begin{array}{c}\text { Konsentrasi } \\
\text { Bunga Rosella }\end{array}$} & \multicolumn{5}{|c|}{ Analisis kimia } \\
\hline & & pH & $\begin{array}{c}\text { Vitamin C } \\
(\mathrm{mg} / 100 \\
\mathrm{ml})\end{array}$ & $\begin{array}{c}\text { Padatan } \\
\text { Terlarut } \\
(\%)\end{array}$ & $\begin{array}{c}\text { Aktivitas } \\
\text { Antioksidan } \\
\text { DPPH (\%) }\end{array}$ & $\begin{array}{c}\text { Gula } \\
\text { Total } \\
(\%)\end{array}$ \\
\hline \multirow[t]{3}{*}{5 gram } & 5 gram & $3,30^{c}$ & $16,57^{\mathrm{a}}$ & $38,33^{\mathrm{ab}}$ & $18,13^{\mathrm{a}}$ & $9,08^{a}$ \\
\hline & 10 gram & $3,10^{\mathrm{bc}}$ & $17,84^{\mathrm{b}}$ & $40,00^{\mathrm{bc}}$ & $16,97^{\mathrm{a}}$ & $9,14 a$ \\
\hline & 15 gram & $2,87^{\mathrm{a}}$ & $18,35^{\mathrm{bc}}$ & $42,33^{\text {de }}$ & $12,75^{\mathrm{a}}$ & $8,71^{\mathrm{a}}$ \\
\hline \multirow[t]{3}{*}{10 gram } & 5 gram & $3,26^{\mathrm{bc}}$ & $18,87^{\mathrm{cd}}$ & $37,33^{\mathrm{a}}$ & $26,93^{a}$ & $9,39^{a}$ \\
\hline & 10 gram & $3,33^{\mathrm{cd}}$ & $19,11^{\mathrm{cd}}$ & $41,00^{\mathrm{cd}}$ & $9,07^{\mathrm{a}}$ & $8,98^{a}$ \\
\hline & 15 gram & $2,93^{\mathrm{ab}}$ & $19,63^{\text {de }}$ & $41,67^{\mathrm{cd}}$ & $13,27^{\mathrm{a}}$ & $8,67^{\mathrm{a}}$ \\
\hline \multirow[t]{3}{*}{15 gram } & 5 gram & $3,87^{\mathrm{e}}$ & $20,40^{\mathrm{e}}$ & $41,33^{\mathrm{cd}}$ & $48,97^{b}$ & $8,55^{\mathrm{a}}$ \\
\hline & 10 gram & $3,67^{\text {de }}$ & $20,65^{\mathrm{fg}}$ & $42,33^{\text {de }}$ & $9,60^{a}$ & $8,83^{\mathrm{a}}$ \\
\hline & 15 gram & $3,27^{\mathrm{bc}}$ & $21,41^{\mathrm{g}}$ & $44,33^{\mathrm{e}}$ & $22,17^{\mathrm{a}}$ & $8,86^{\mathrm{a}}$ \\
\hline
\end{tabular}

Keterangan: Rerata yang diikuti huruf yang berbeda pada kolom yang sama menunjukkan beda nyata pada uji Tukey taraf signifikan $5 \%$.

\section{Derajat Keasaman (pH)}

Purata hasil analisis sidik ragam menunjukkan bahwa perlakuan daun kelor, bunga rosella berbeda nyata sedangkan kombinasinya berbeda tidak nyata. Derajat keasaman $(\mathrm{pH})$ tertinggi pada sirup herbal ditunjukkan pada perlakuan kelor:rosella 15:5 dengan nilai 3,87, sedangkan $\mathrm{pH}$ yang terendah pada sirup herbal kelor : rosella dengan perbandingan 5:15 dengan nilai 2,87. Pada penelitian sirup herbal kelor-rosella ini, dapat disimpulkan bahwa $\mathrm{pH}$ yang rendah dipengaruhi oleh kadar bunga rosella sehingga menciptakan rasa asam dan $\mathrm{pH}$ yang lebih tinggi dipengaruhi oleh semakin banyaknya daun kelor. Hal tersebut didukung oleh $\mathrm{pH}$ daun kelor yang tinggi yaitu 4,6 (Diantoro, 2015) sedang $\mathrm{pH}$ bunga rosella lebih rendah 3,46 (Ali, 2013).

pH tertinggi sirup kelor-rosella tampak pada perlakuan kelor:rosella (15:5), yaitu 3,87 semakin banyak penambahan kelor, menyebabkan pH sirup kelor-rosella semakin tinggi. Hal ini sejalan dengan hasil penelitian Rahmawati (2015) yang menyatakan bahwa penambahan sari daun kelor dengan lama fermentasi yang sama akan menaikkan $\mathrm{pH}$ yoghurt, sehingga yoghurt menjadi kurang asam. Semakin tinggi konsentrasi sari daun kelor yang ditambahkan maka $\mathrm{pH}$ yoghurt semakin tinggi.

Menurut penelitian Zaelani (2014), nilai pH ekstrak rosella murni dengan minuman pisang rosella (konsentrasi rosella $25 \%$ dan $\mathrm{pH}$ $2,95)$ lebih tinggi dibanding $\mathrm{pH}$ ekstrak rosella (konsentrasi 25\% dengan $\mathrm{pH} 2,46$ ).

\section{Vitamin C}

Purata hasil analisis sidik ragam menunjukkan bahwa perlakuan daun kelor, bunga rosella dan kombinasinya berbeda nyata. 
Kadar vitamin $C$ tertinggi pada perlakuan kelor:rosella 15:15 yaitu 21,41 mg/10o ml sedangkan kadar vitamin $C$ terendah pada sirup herbal kelor:rosella dengan perbandingan 5:5 yaitu 16,57 mg/100 ml. Bunga rosella segar memiliki kandungan vitamin $C$ sebesar 214,68/100 g (Widyanto dan Nelistya, 2008) dan kandungan vitamin $C$ rosella kering sebesar 2,444/10o g (Maryani dan Kristina, 2008), kelor memiliki kandungan vitamin $C$ sebesar 220 mg/100 g (Rukmana, 2005). Pada penelitian sirup herbal kelor-rosella ini dapat disimpulkan bahwa tingginya kadar vitamin $C$ dipengaruhi oleh komposisi bunga rosella dan daun kelor yang semakin meningkat karena kedua bahan mengandung vitamin $C$ yang cukup tinggi. Menurut Winarno (2004), pada proses pengolahan sirup dilakukan pemanasan, vitamin $C$ seluruhnya ikut larut dan vitamin $C$ yang terdapat dalam bahan dilindungi oleh gula pada waktu proses pengolahan, sehingga vitamin $C$ yang hilang pada waktu proses pengolahan tidak terlalu banyak.

\section{Total Padatan Terlarut}

Purata hasil analisis sidik ragam menunjukkan bahwa perlakuan daun kelor, bunga rosella dan kombinasinya berbeda nyata. Total padatan terlarut tertinggi pada sirup herbal ditunjukkan perlakuan kelor:rosella dengan perbandingan 15:15 dengan nilai 44,33\%, sedangkan total padatan terlarut terendah pada sirup herbal kelor:rosella dengan perbandingan 10:5 dengan nilai 37,33\%. Kadar total padatan terlarut pada sirup herbal berkisar antara 37,33\% sampai $44,33 \%$. Pektin salah satu kandungan padatan terlarut, sehingga konsentrasi bunga rosella mempengaruhi tingginya kadar padatan terlarut, bunga rosella mengandung asam organik yang dapat meningkatkan padatan terlarut pada minuman (Winarti, 2006). Penelitian Friskilla dan Rahmawati (2018), total padatan terlarut pada minuman teh hitam dengan daun kelor, formulasi teh hitam yang semakin banyak menyebabkan kandungan bahan yang terlarut di dalam larutan semakin tinggi, dibandingkan dengan penambahan jumlah daun kelor yang banyak, dan berbanding terbalik dengan perlakuan penambahan daun kelor yang semakin banyak. Hasil penelitian sirup kelor-rosella menunjukkan total padatan terlarut cenderung semakin tinggi dengan semakin banyaknya jumlah daun kelor dan rosella, rosella mengandung asam organik dan anorganik serta senyawa lain yang mengandung padatan terlarut sirup. Daun kelor mengandung senyawa yang cukup menyumbang jumlah padatan terlarut.

\section{Aktivitas Antioksidan Metode DPPH}

Purata hasil analisis sidik ragam menunjukan bahwa perlakuan daun kelor, bunga rosella dan kombinasinya berbeda nyata. Aktivitas antioksidan tertinggi pada sirup herbal terdapat pada perlakuan kelor:rosella dengan perbandingan $15: 5$ dengan nilai $48,97 \%$, sedangkan aktivitas antoksidan terendah pada sirup herbal kelor:rosella dengan perbandingan 10:10 dengan nilai 9,07\%. Kedua bahan pada sirup herbal kelor-rosella mempengaruhi aktivitas antioksidan, Kadar aktivitas antioksidan pada sirup herbal berkisar antara 9,07\% sampai 48,97\%. Aktivitas antioksidan daun kelor sebesar 81,5\% (Sari, 2015). Pada penelitian sirup herbal kelor-rosella ini dapat disimpulkan bahwa kadar aktivitas antioksidan tertinggi dipengaruhi oleh kandungan antioksidan bunga rosella. Pada perlakuan kelor:rosella (10:5) dan kelor-rosella (15:5) menunjukkan kenaikan yang signifikan, hal tersebut dikarenakan pembuatan sirup dilakukan pada hari yang berbeda sehingga mempengaruhi kualitas bahan baku. Penelitian Hastuti (2012), pemanasan yang menyebabkan meningkatnya aktivitas penangkap radikal bebas sehingga daya larut komponen aktif meningkat disebabkan oleh dinding sel yang rusak akibat pemanasan tersebut. Aktivitas yang tinggi disebabkan oleh bunga rosella yang memiliki komponen bioaktif, seperti pigmen dan senyawa flavonoid yang dapat berperan sebagai antioksidan (Hirunpanich et al, 2005).

\section{Gula Total}

Purata hasil analisis sidik ragam menunjukkan bahwa perlakuan daun kelor, bunga rosella dan kombinasinya berbeda tidak nyata. Kadar gula total tertinggi pada sirup herbal ditunjukan perlakuan kelor:rosella (10:5) dengan nilai 9,39\%, sedangkan kadar gula total terendah pada sirup herbal kelor:rosella dengan perbandingan 15:5 dengan nilai $8,55 \%$. 
Komponen bunga rosella dan daun kelor pada sirup herbal kelor-rosella mempengaruhi tinggi rendahnya kadar gula di dalam sirup herbal kelor-rosella. Pada penelitian sirup kelor-rosella ini dapat disimpulkan bahwa tinggi rendahnya kandungan gula dipengaruhi oleh komposisi daun kelor dan bunga rosella. Kadar gula total pada sirup herbal berkisar antara $8,55 \%$ sampai
9,39\%. Menurut penelitian Yuliani et al (2011), penurunan kadar gula total pada minuman jeli rosella disebabkan karena gula dengan asam kuat akan teroksidasi menjadi asam dikarboksilat (aldosa akan teroksidasi menjadi asam aldarat, contohnya galaktosa akan berubah menjadi asam galaktarat).

\section{Uji Organoleptik}

Tabel 2. Rangkuman Hasil Analisis Uji Organoleptik Sirup Herbal Kelor-Rosella

\begin{tabular}{|c|c|c|c|c|c|c|}
\hline \multirow{2}{*}{$\begin{array}{l}\text { Konsentrasi } \\
\text { Daun Kelor }\end{array}$} & \multirow{2}{*}{$\begin{array}{c}\text { Konsentrasi } \\
\text { Bunga Rosella }\end{array}$} & \multicolumn{5}{|c|}{ Analisis Organoleptik } \\
\hline & & Warna & $\begin{array}{l}\text { Flavor } \\
\text { Kelor }\end{array}$ & $\begin{array}{c}\text { Flavor } \\
\text { Rosella }\end{array}$ & $\begin{array}{r}\text { Rasa } \\
\text { Asam }\end{array}$ & $\begin{array}{c}\text { Kesukaan } \\
\text { Keseluruhan }\end{array}$ \\
\hline \multirow[t]{3}{*}{5 gram } & 5 gram & $1,74^{\mathrm{a}}$ & $2,09^{a}$ & $1,89^{\mathrm{ab}}$ & $1,79^{\mathrm{a}}$ & $2,15^{\mathrm{a}}$ \\
\hline & 10 gram & $2,30^{\mathrm{ab}}$ & $2,19^{\mathrm{a}}$ & $2,47^{\mathrm{abc}}$ & $2,73^{\text {abcd }}$ & $2,43^{\mathrm{a}}$ \\
\hline & 15 gram & $3,82^{d}$ & $1,97^{\mathrm{a}}$ & $3,09^{c}$ & $3,94^{\mathrm{d}}$ & $2,80^{a}$ \\
\hline \multirow[t]{3}{*}{10 gram } & 5 gram & $2,22^{\mathrm{ab}}$ & $2,17^{\mathrm{a}}$ & $1,69^{\mathrm{a}}$ & $2,05^{\mathrm{ab}}$ & $2,71^{\mathrm{a}}$ \\
\hline & 10 gram & $2,8 o^{b c}$ & $2,33^{\mathrm{a}}$ & $2,63^{\mathrm{abc}}$ & $2,36^{\mathrm{abc}}$ & $2,61^{\mathrm{a}}$ \\
\hline & 15 gram & $3,43^{\mathrm{cd}}$ & $2,03^{\mathrm{a}}$ & $3,03^{b c}$ & $3,44^{\mathrm{cd}}$ & $2,56^{\mathrm{a}}$ \\
\hline \multirow[t]{3}{*}{15 gram } & 5 gram & $1,80^{\mathrm{a}}$ & $2,56^{b}$ & $1,89^{\mathrm{ab}}$ & $1,87^{\mathrm{a}}$ & $1,72^{\mathrm{a}}$ \\
\hline & 10 gram & $2,15^{\mathrm{ab}}$ & $2,71^{\mathrm{ab}}$ & $2,63^{\mathrm{abc}}$ & $2,09^{\mathrm{ab}}$ & $2,75^{\mathrm{a}}$ \\
\hline & 15 gram & $3,59^{\mathrm{cd}}$ & $2,80^{a}$ & $3,04^{\mathrm{bc}}$ & $3,15^{\text {bcd }}$ & $2,5^{2^{a}}$ \\
\hline
\end{tabular}

Keterangan:

Warna

Flavor Kelor

Flavor Rosella

Rasa Asam

: Angka tertinggi menunjukan warna merah tua

: Angka tertinggi menunjukan flavor kelor semakin terasa langu

Kesukaan keseluruhan

: Angka tertinggi menunjukan flavor rosella semakin terasa asam

: Angka tertinggi menunjukan rasa sirup semakin asam

\section{Warna}

Warna merupakan faktor untuk menentukan mutu dan secara visual warna tampil lebih dahulu dan kadang-kadang selalu menentukan, sehingga warna dijadikan atribut organoleptik yang penting dalam suatu bahan pangan, warna dapat menentukan mutu suatu bahan pangan dan dapat digunakan sebagai parameter kesegaran bahan makanan (Winarno, 2004). Purata hasil analisis sidik ragam menunjukkan bahwa perlakuan daun kelor tidak berbeda nyata, sedangkan perlakuan bunga rosella dan kombinasinya berbeda nyata. Perlakuan kelor:rosella dengan perbandingan 5:15 memilikinilai tertinggi dengan nilai 3,82 (merah tua), sedangkan kelor:rosella dengan perbandingan 5:5 memiliki nilai terendah dengan nilai 1,74 (merah muda) semakin banyak jumlah rosella, warna semakin merah.

\section{Flavor Kelor}

Rasa merupakan penilaian yang berhubungan pada komponen bahan yang ditangkap dengan indera pengecap (lidah) dan aroma berhubungan dengan komponen volatil suatu bahan dengan indera pencium (hidung), semakin banyak komponen volatil di bahan, maka aroma yang terbentuk semakin tajam (Kartika et al, 1988). Purata hasil analisis sidik ragam menunjukkan bahwa perlakuan daun kelor berbeda nyata, perlakuan bunga rosella berbeda tidak nyata dan sedangkan kombinasinya berbeda nyata. Perlakuan kelor:rosella dengan perbandingan 15:5 memiliki flavor kelor yang kuat dengan nilai 3,80, sedangkan kelor:rosella dengan perbandingan 
5:5 memiliki flavor kelor yang sedikit dengan nilai 1,97. Pada penelitian sirup herbal kelorrosella ini dapat disimpulkan, uji flavor kelor didominasi oleh kandungan daun kelor yang lebih banyak daripada bunga rosella karena daun kelor sendiri memiliki sifat langu yang disebabkan oleh kandungan enzim lipoksidase yang terhidrolisis atau menguraikan lemak menjadi senyawa penyebab langu (Zakiatul, 2016).

\section{Flavor Rosella}

Indikasi cita rasa atau flavor suatu produk ditimbulkan oleh kesan dari kedua indra manusia yaitu pembau dan perasa dalam mengamati flavor memiliki dua cara, yaitu yang pertama melalui indera pembau, dimana rangsangan akan diterima oleh region alfacktoria yaitu suatu bagian pada atas rongga hidung, sedangkan yang kedua lewat indera pengecap yaitu mulut bagi yang timbul dari kedua indera ini mengindikasikan cita rasa atau flavor dari suatu produk tersebut (Kartika et al, 1988). Purata hasil analisis sidik ragam menunjukkan bahwa perlakuan daun kelor berbeda tidak nyata, perlakuan bunga rosella berbeda nyata dan sedangkan kombinasinya berbeda tidak nyata. Perlakuan kelor:rosella dengan perbandingan 5:15 memiliki flavor rosella yang kuat dengan nilai 3,09, sedangkan kelor:rosella dengan perbandingan 10:5 memiliki flavor kelor yang sedikit dengan nilai 1,69. Pada penelitian sirup herbal kelor-rosella ini dapat disimpulkan dari uji organoleptik, uji flavor rosella dengan kandungan rosella yang lebih banyak dibandingkan kandungan daun kelor.

\section{Rasa Asam}

Rasa merupakan parameter mutu yang terindra oleh alat pengecap pada lidah manusia, merupakan gabungan dari berbagai macam rasa yang terpadu sehingga menciptakan cita rasa yang utuh sehingga menimbulkan rasa baru atau utuh (Winarno, 2004). Purata hasil analisis sidik ragam menunjukkan bahwa perlakuan daun kelor berbeda tidak nyata, perlakuan bunga rosella berbeda nyata sedangkan kombinasinya berbeda tidak nyata. Perlakuan kelor:rosella dengan perbandingan 5:15 memiliki rasa asam yang kuat dengan nilai 3,94, sedangkan kelor:rosella dengan perbandingan 5:5 memiliki rasa asam yang sedikit dengan nilai 1,79 semakin banyak penambahan rosella, sirup menjadi semakin asam dan aroma rosella semakin terasa. Pada penelitian sirup herbal kelor-rosella ini dapat disimpulkan dari uji organoleptik, uji rasa asam ini dipengaruhi oleh komposisi daun kelor dan bunga rosella.

\section{Kesukaan Keseluruhan}

Penilaian kesukaan keseluruhan menunjukkan kesukaan secara umum pada sirup herbal kelor-rosella dari sifat-sifat uji organoleptik terhadap penerimaan panelis pada produk sirup herbal kelor-rosella secara keseluruhan. Purata hasil analisis sidik ragam menunjukan bahwa perlakuan daun kelor tidak berbeda nyata, perlakuan bunga rosella berbeda nyata sedangkan kombinasinya berbeda tidak nyata. Perlakuan kelor:rosella dengan perbandingan 5:15 lebih banyak disukai yaitu sebesar 2,80, sedangkan kelor:rosella dengan perbandingan 15:5 sedikit disukai yaitu sebesar 1,72. Pada penelitian sirup herbal kelor-rosella ini dapat disimpulkan panelis menyukai sirup kelor-rosella dengan perbandingan 5:15. Sesuai pendapat Winarno (2004) yang menyatakan bahwa selain komponen (bau, rasa, dan rangsangan mulut) komponen yang paling penting adalah timbulnya perasaan seseorang setelah memakannya.

\section{KESIMPULAN}

Sirup herbal kelor-rosella yang memiliki aktivitas antioksidan tertinggi dengan perbandingan kelor:rosella sebanyak 15:5, aktivitas antioksidan sebesar 48,97\%, $\mathrm{pH} 3,87$, vitamin $\mathrm{C} 20,40 \mathrm{mg} / 100 \mathrm{ml}$, total padatan terlarut $41,33 \%$, gula total $13,82 \%$, serta uji organoleptik pada warna merah cerah $(1,80)$, flavor kelor terasa (2.56), flavor rosella sedikit terasa $(1,89)$, rasa asam terasa $(1,87)$.

\section{DAFTAR PUSTAKA}

Ali, F., Ferawati, dan Arqomah, R., 2013. Ekstraksi Zat Warna dari Kelompok Bunga Rosella (Studi Pengaruh Persentase Asam Asetat dan Asam Sitrat). Jurnal Teknik Kimia 
(19): 26-33.

Broin, M., 2010. Growing and processing moringa leaves. France: Imprimerie Horizon.

Diantoro, A., Rohman, M., Ratna B, dan Hapsari, T.P., 2015. Pengaruh Penambahan Ekstrak Daun Kelor (Morringa oleifera L.) terhadap Kualitas Yoghurt. Jurnal Teknologi Pangan (6): 59-66.

Rahmawati, F. Y., 2018. Pengembangan Minuman Teh Hitam dengan Daun Kelor (Morringa oleifera L.) sebagai Minuman Menyegarkan. Jurnal Industri Kreatif dan kewirausahaan 1(1): 22-31.

Hastuti, N. D., 2012. Pembuatan Minuman Fungsional dari Madu dan Ekstrak Rosella (Hibiscus Sabdariffa Linn). Jurnal Teknologi Pangan 3(1): 29-63. Kalimantan Barat: Tenaga Pengajar Politeknik Ketapang Kalimantan Barat

Hirunpanich, V., Utaipat, A., Morales, N.P., 2005. "Antioxidant effects of Aqueos Extract from Dried Calyx of Hibiscus Sabdariffa Linn. (Roselle) in Vitro Using Rat LowDesity Lipoprotein (LDL)". Journal of Pharmaceutical Society of Japan (28): 481-484.

Kartika, B., Hastuti, P., dan Supartono, W., 1988. Pedoman Uji Inderawi Badan Pangan. Yogyakarta: Pusat Antar Universitas Pangan dan Gizi Universitas Gadjah Mada.

Maitimu, C. V, Legowo, A. M, Al-Baari., 2012. Parameter Keasaman Susu Pateurisasi dengan Penambahan Ekstrak Daun Aileru (Wightia caligria). J. Aplikasi Teknologi Pangan 1 (1): 7-11.

Maryani, H., dan Kristina, L., 2008. Khasiat dan Manfaat Rosella. Jakarta: Agromedia Pustaka

Mukaromah, U, Hetty, dan Aminah 2010. Kadar Vitamin C, Mutu Fisik Dan Mutu Organoleptik Sirup Rosella (Hibiscus Sabdariffa, L) Berdasarkan Cara Ekstraksi. Jurnal Pangan dan Gizi 1(1): 43-51.

Pomeranz, Y., dan Meloan, C.E., 1980. Food Analysis: Theory and Practice. Second Edition. New York: Van Nostrand
Reinhold Company.

Rahmawati, E., 2015. Kadar Protein, pH dan Jumlah Bakteri Asam Laktat Yoghurt Susu Sapi dengan Variasi Penambahan Sari Daun Kelor dan Lama Fermentasi Yang Berbeda. Skripsi. Surakarta: Fakultas Keguruan dan Ilmu Pendidikan Universitas Muhadmmadiyah

Rukmana, R., 2005. Bertanam Sayuran di Pekarangan. Yogyakarta: Kanisius.

Sari, M.A., 2015. Aktivitas Antioksidan Teh Daun Alpukat (Persea umerinana Mill) dengan Variasi Teknik dan Lama Pengeringan. Skripsi. Surakarta: Universitas Muhammadiyah

Sudarmadji, S., Haryono, B., dan Suhardi., 1997. Analisa Bahan Makanan dan Pertanian. Yogyakarta: Liberty.

Widyanto, P. S dan A. Nelistya, 2008. Rosella Aneka Olahan. Khasiat dan Ramuan. Jakarta: Penebar Swadaya.

Winarno, F.G., 2004. Kimia Pangan dan Gizi. Jakarta: PT. Gramedia Pustaka Utama

Winarti, S., 2006. Minuman Kesehatan. Surabaya: Trubus Agrisarana.

Yen, G.O., dan Chen, Y. 1995. Antioxidant Activity of Vrious Tea Extrcts in Relation to Their Antimutagenicity. Journal of Agricultural and Food Chemistry 43(1):27-32.

Yuliani, Marwati, Wahyu, M.R.F. 2011. Studi Variasi Konsentrasi Ekstrak Rosella (Hibiscus sabdariffa L.) dan karagenan terhadap Mutu Minuman Jeli Rosella. Skripsi. Samarinda: Universitas Mulawarman.

Zaelani, M., 2014. Pengaruh Penambahan Konsentrasi Ekstrak Bunga Rosella terhadap Aktivitas Antioksidan Minuman Fungsional Pisang-Rosella. Skripsi. Bogor: Departemen Gizi Masyarakat Fakultas Ekologi Manusia Institut Pertanian Bogor.

Zakiatul, A.R., 2016. Studi tentang Tingkat Kesukaan Responden terhadap Penganekaragaman Lauk Pauk dari Daun Kelor (Moringa oleivera). E-Journal Boga 5: 17-22. 